\title{
Noradrenaline Measurement
}

National Cancer Institute

\section{Source}

National Cancer Institute. Noradrenaline Measurement. NCI Thesaurus. Code C74868.

The determination of the amount of noradrenaline hormone present in a sample. 